SMART Journal, Volume 6, No. 2, August 2020, Page 72- 81

ISSN Cetak : :2356-2048

ISSN Online : $2356-203 \mathrm{X}$

\title{
VOCABULARY BOOK FOR DEAF STUDENTS
}

\author{
Nur Fefti Agustina Putri ${ }^{1)}$, Fitri Wulandri ${ }^{2)}$, Rahmatika Kayyis ${ }^{3)}$ \\ ${ }^{12) 33}$ English Education Department of FKIP UMPRI \\ Email Correspondence: feftiputri@gmail.com
}

\begin{abstract}
This study was a research and development $(R \& D)$ study designed which involved: need analysis, design, development, implementation, and evaluation. The data were gathered through observation, questionnaires, interview, validation technique and test.The result of this study showed that: (1) the students need specific material about daily activity; (2) the design of book, learning English vocabulary which contain picture; (3)the deaf students' wants Learning English use media images because image make it easier for them to remember English vocabulary, and they are able to describe facial expressions and gestures; (4) when learn English vocabulary they must remember each word by practicing it.
\end{abstract}

Keywords: Vocabulary Book, Deaf Students, Material Development

\section{INTRODUCTION}

Children are born with their own uniqueness and capability. Somehow the children may be born with special needs and capability that may different with the others, so it called as special children. Haryono, Syaifudin, A. \& Widiastuti (2015) states children with special needs created by God on earth there is no term a failed product. Cognitive or physical disabilities and deficiencies will not be able to prevent a person from achieving the top. In fact, they also harbor enormous potential. The child categorized as children with special needs are children who experience disabilities mental, learning disabilities or attention deficit, emotional or behavioral disorders, physical barriers, communication, autism, traumatic brain injury, hearing impairment, and vision problems (Romadon\&Supena, 2020). Moreover, Anggraini (2013) states that children who are categorized as children with special needs are children who have mental retardation, learning disabilities or attention disorders,

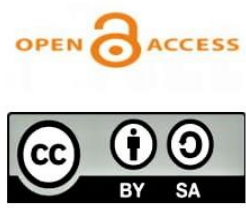

Creation is distributed under the Creative Commons License Attribution

Share Alike 4.0 International Published in https://ejournal.umpri.ac.id/index.php/smart/index

SMART Journal: Journal of English Language Teaching and Applied

Linguistics 
emotional or behavioral disorders, physical disabilities, communication, autism, traumatic brain injury, hearing impairment, visual impairment, and children with special talents

Education is very important for humans to be able to achieve social welfare, including children with special needs $(\mathrm{ABK})$. However, not all humans who are born on this earth are born with perfection so that they can easily get education in general; therefore the government is obliged to provide education for those with special needs, because children with special needs need special attention in order to get optimal results like children. who is the same age as him. All humans are born with different strengths, so it is the duty of parents and teachers to look for the strengths of these children, including children with special needs. We often see children with special needs appearing on the television screen with the various advantages they have. Even from the psychological side they seem to be more grateful for the life they live now (Rahmawati, 2018).

. The primary purpose of a special needs education is to help students with physical, mental, behavioral and social disorders to be able to develop attitudes, knowledge and skills as individuals and community members in providing reciprocity with the surrounding social, cultural and natural environment and can develop abilities in world of work or attend further education.

SMALB Negeri Pringsewu interpreted as a state educational institution whose school policies are regulated and stipulated by the government. This school is different from other schools because it is especially for students with special needs, each child is classified and included in the class according to their class of needs. The subject matter was adapted to their abilities and potential. SMALB Negeri Pringsewu not only given academic knowledge but the teacher tried to improve the talents of the students according to the talents they had as a provision so that students could socialize and interact with the environment in which they were. English learning materials have a 
Vocabulary Book...

crucial part in teaching and learning processes in the classrooms. The school needs English materials based on the recent curriculum hat also researcher who are related to materials and media processes in SMALB Negeri Pringsewu; the students have not been suitable for syllabus and students need. However, there are some problems found by the researcher that are related to materials and media used in the teaching and learning process in SMALB Negeri Pringsewu of the English materials used in learning English for the students haven't suitable with the syllabus, and students need.Students really need material resources, especially, for material vocabulary English that are in accordance with the need to improve their ability to receive, understand about word and the meaning of word, enhance the vocabulary and the most important thing is to more extensive information than before. Because in order to communicate using English in oral and written form, the students should prepare themselves with vocabulary mastery (Kayyis, 2015)

Because most of the material that is available is in accordance with their environment and causes them to be able to apply it in their daily lives, designing materials that can be related to students' daily lives, which will be more beneficial because if the material is adjusted with the environment, they will understand more quickly and be able to apply information from book to everyday life.

Based on the problems identified above, the researcher focuses on developing English vocabulary materials for deaf students of SMALB Negeri Prigsewu. The developed materials are in the form of the module which consists of material for English vocabulary supported with images and videos to facilitate students in understanding vocabulary.

\section{RESEARCH METHOD}

The research method is a series of methods or activities for conducting research based on basic assumptions, philosophical views, questions, and issues faced in 
research. The objective of this research is to develop appropriate model of English learning materials for deaf students of SMALB Negeri pringswwu. Therefore, this research is classified as Research and Development. According to Sugiyono (2012) research and development is a research method used to produce certain products, and test the effectiveness of these products.

Research and Development uses qualitative and quantitative approaches in conducting research and collecting data. Research and development as a process used to develop products in education. The results of research and development not only to develop products are provided, but also to discover new knowledge in developing material.

The procedure of this research refers to the system model that proposed by Sugiyono (2012) states steps that must be followed to produce products include; Potential and problem stages, data collection, product design, design validation, product design revisions, product trials, product revisions, usage tests, product revisions, and mass production.

\section{RESULT AND DISCUSSION}

\section{Learning needs}

The importance of doing a need analysis in ESP aims that the language taught is really the language needed in the field to be occupied by learners Kayyis (2019):

Input as stated in Nunan (2004) states that 'Input' refers to the spoken, written and visual data that learners work with in the course of completing a task. Inputs can come from various sources which are then made into learning material. The following are the results of the questionnaire related to the type of input text that students want in the learning process. 
Vocabulary Book...

In learning Englishvocabulary, most of deaf students want to have input which contain pictures $(83 \%)$, whereas $(100 \%)$ of the students wanted to learn daily activity materials.

Procedure, Procedure 'determines what students will actually do with the input that has been given. Here are the results of the needs analysis questionnaire in term of learning procedures. In terms of Vocabulary Task, most of students (83\%) want to have tasksof finding new words and their meaning, whereas (100\%) of the students wanted Creating sentences usingvocabulariesprovided, while $(83 \%)$ students want to complete blanks on incomplete sentences.

The role of the teacher refers to the expected part of the student carried out by the natural teacher carrying out learning process as well as social and interpersonal relationships between participants. From the text above, it can be concluded that the role of the teacher according to the (100\%) students is creating a good atmosphere to get the students involve in the classroom activity consider that the teacher should supporting and guiding the students to use their creativity.

Learner's Role, The role of students refers to the part that is expected to be played by students in carrying out learning process as well as social and interpersonal relationships between participants. From the text above, it can be concluded that of the students $(83 \%)$ consider that they must follow the teacher's instructions to complete the task, then (100\%) when learn English vocabulary they must remember each word by practicing it.

\section{Material's Design}

The first draft of materials consists of three units. Each unit has three main parts; Introduction, Lesson Proper and Reinforcement. The design of the unit is shown in the diagram below and the elaboration of the unit's parts is in the following paragraphs. 
The Introduction stage comes first in each unit. It covers warm-up activity which aims to build the background knowledge of the studentsabout what they will learn in the unit(Lets learn). Before the warm-up activity,there is a description of the unit's objectives which is placed in thevery front of the page. It explains the objectives of the unit.

The next stage is Lesson Proper. The lesson proper consists of two sections, they are spoken (Let's Look and practice) and written (Let's read and write). Each section follows the scientific steps which isrequired by Curriculum 2013; i) Observing: students read or listen totexts to list items they want to know in order to understand andproduce texts, ii) Questioning: students formulate questions andpropose temporary answers to their questions, iii) Collecting,Analyzing, Communicating: students sort out, classify, and identifyrelationships among the data to find out patterns to answer theformulated questions, iv) Creating: students create texts to express thoughts/ideas.

The last stage is Reinforcement. It has two parts. The first is Review. There are some activities in this part which is intended tocheck the students' understanding about what they have learned. Then,there is a Reflection to self-assess the students' level of understanding.

Based on the results of needs analysis, it can be seen that learners need to have good English language skills especially for vocabulary. They need to improve their English vocabulary to make it easy for students to achieve their learning goal. In the questionnaire that was distribute to the student they want to learn English for passing the national examination, and they need all aspect of learning English but because of question is dominating in the national examination; so they need to mastering English language especially for vocabulary mastery to get better result from it. English in SMALB Negeri Pringsewu, the students need to learn vocabulary that for make them to achieve the learning goals and make them ease to lead higher level. 
Vocabulary Book...

Here the researcher designing material include of vocabulary mastery aspect on it as material to add the available source of material. The theme of this design is about daily activity by considering student needs to have a material source that is not only become learning material but also they can use the knowledge and find the theme of material in their daily life. So, they can apply it in their life.

The material has fiveactivity to supporting the learning process; that are:Lets learn, lets read, lets look, lets do it, and the last is lets conclude. Each activity have their own role to make the learning process more organized because in this material the researcher arrange each activity based on the learning process and try to maximize each stage of activity in the book.

From the results of expert judgment validation, it can be seen that the materials developed were valid and appropriate for the learners because the material in interval of $2.5<\mathrm{X}<3.24$. It can be concluded that the material is categorized as "Good".

\section{CONCLUSIONS}

The goals of the research were to design an English Vocabulary book to improve the Vocabulary English of the deaf students at SMALB Negeri Pringsewu, to give a meaningful contribution to English language teaching especially for SMALB Negeri Pringsewu, and to improve the quality of human being by conducting this research, especially for the researcher. The goals came from identifying the problems of conduction this research. Based on the research's goals and problems, two research questions were formulated. The first questions investigated the schematic model of the designed English vocabulary book. The second question asked about the end product of the research which was the module vocabulary english.

The first two phases of Borg and Gall Design model were conducted to answer the first question. The first phase is Analysis which aims to collect the data on 
the needs and context analysis. The researcher reviewed some books, articles, and previous related studies to collect the data about the real needs. The confirmation of the findings was done by interviewing the deaf students by angket . To do the context analysis, the researcher conducted interview with English teachers of SMALB Negeri Pringsewu. In designing the materials, the researcher formulated the general goals, specific learning objectives, units, topics, and activities in accordance with the real needs collected from the analysis phase.

The last three steps of Bork and Gall Design model were conducted to answer the second question of the research. The researcher developed the vocabulary English book, evaluated the first draft to the experts, implemented the course book and gained the feedback and suggestions from the user validation questionnaire.

The result of the expert and user validation showed that the designed Vocabulary English book for deaf students was good and considered as practical as a whole. The students were interestedinand motivated to learn English with the course booksince it is learnable and useful. The designed Vocbulary English book is considered acceptable with a few revisions. The main revision is about clarity of instruction and each material must use video with sign language.

The Vocabulary English book for deaf students is already good, effective and acceptable. The course book is designed through empirical and theoretical ways. Therefore, it contributes for the science of the book itself. This research has the authentic learning materials which is meaningful to the development of Vocabulary English learning for deaf students at SMALB Negeri PringsewuThe English teachers may use this book as one of the references to teach the students with functional topics, various activities, and more speaking practices. The students who use the book will get the benefit which is improving their Vocabulary especially vocabulary for daily activity. 
Vocabulary Book...

From the evaluation, the students liked the course book because of its

effectiveness. Lastly, the researcher could improve her quality in designing an Vocabulary English book through some revisions. The skillsin producing materials were improved by the theories and practice.

\section{REFERENCES}

Anggraini, R. R. (2013). Persepsi Orangtua Terhadap Anak Berkebutuhan Khusus (Deskriptif Kuantitatif di SDLB N.20 Nan Balimo Kota Solok. Jurnal Ilmiah Pendidikan Khusus. 2(1), 258-265. July, 24, 2020. http://ejournal.unp.ac.id/index.php/jupekhu/article/view/951/807.

Haryono, Syaifudin, A. \& Widiastuti, S. (2015). Evaluasi Pendidikan Inklusif Bagi Anak Berkebutuhan Khusus (ABK) Di Provinsi Jawa Tengah. Jurnal Penelitian Pendidikan. 32(2), 119-126. 24 Juli 2020. https://journal.unnes.ac.id/nju/index.php/JPP/article/view/5057/4113.

Kayyis, R. \& Wulandari, F. (2019). What Math Students Need to Learn English?

INOVISH Journal.4(1), 84-90. July 24, 2020.

http://ejournal.polbeng.ac.id/index.php/IJ/article/view/949/0.

Kayyis, R. (2015). Building Vocabulary Using Pop Songs. SMART Journal. 1(1), 32-42. July 24, 2020.

https://webcache.googleusercontent.com/search?q=cache:P7mKPuztB6oJ:https://ejo urnal.umpri.ac.id/index.php/smart/article/download/89/40+\&cd=1\&hl=id\&ct=clnk\& $\mathrm{gl}=\mathrm{id}$.

Rahmawati, A. (2018). Konsep Pembelajaran PAI bagi Anak Berkebutuhan Khusus di Sekolah Inklusi: Studi Kasus di SD Semai Jepara. Edukasia Islamika. 3(2), 171-183. July 24, 2020. https://doi.org/10.28918/jei.v3i2.1686.

Romadon, M. \&Supena, A. (2020). Persepsi Orangtua Terhadap Anak Berkebutuhan Khusus. Elementaria Edukasia. 3(2), 411-419. July 25, 2020. 
Nur Fefti....

http://ejournal.unp.ac.id/index.php/jupekhu/article/view/951.

Sugiyono. (2012). Metode Penelitian Kuantitatif Kualitatif dan $R \&$ D. Bandung: Alfabeta. 